\title{
Job Satisfaction and Organizational Commitment in Banking Sector: A Comparative Study of Conventional and Islamic Banks
}

Kousar Khand ${ }^{1}$, Salma Khand ${ }^{2}$, Adnan Pitafi ${ }^{1}$

\begin{abstract}
Present research work was carried out to examine the relationship between job satisfaction and organizational commitment, and also the difference in the level of job satisfaction and organizational commitment present in employees of Islamic and Conventional banks at Hyderabad. Data was collected through a structured questionnaire. Pearson correlation coefficient, regression, and Mann-Whitney Test were used to analyze the data. The results of the study demonstrated that job satisfaction had a significant impact on affective, continuance, and normative commitments. The job itself and supervisors were significantly $(\mathrm{P}<0.001)$ correlated with other job facets. A Reward system was seen to be significantly correlated with job-itself, supervision, and coworkers, whereas coworkers with the job itself, reward system, and supervision. Meaningfulness of the job was also significantly correlated with the job itself, supervision and coworkers. However, no significant correlation was found between the meaningfulness of the job and the reward system. The level of organizational commitment was found to be the same in employees of Islamic and Conventional Banks.
\end{abstract}

Keywords: Job satisfaction, affective commitment, continuance commitment, normative commitment, banking sector.

JEL Code: M54, J19

\section{Introduction}

Islamic banking or Sharia banking is a banking system that follows the ethics and values of Islam or the principles of Islamic Sharia. Conversely, a Conventional bank is defined as a system of banking that is based on man-made principles. Worldwide Islamic and Conventional banking sector is facing huge competition and Pakistani banking sector is not an exception to that competition. An organization will not reach the climax of quality in terms of productivity or customer service level if the employees of that organization are not satisfied or are not loyal to the organization (Stewart, 1996). Many organizations know that workers are first to defend and encounter the challenges the organization receives and they help organization to achieve its mission and

${ }^{1}$ Mehran University of Engineering and Technology Jamshoro Sindh Pakistan ${ }^{2}$ Department of Management Sciences, Isra University Hyderabad Pakistan Corresponding Author: s.khand@outlook.com 
Kousar Khand et al Job Satisfaction and Organizational Commitment in Banking Sector: A Comparative Study of

objectives. This is why organizations look for motivated, responsible, and dedicated staff instead of those who are careless, inactive, and unfaithful (Hashmi, 2012). Research has proved that employees who are more engaged and happy are more productive than those who lack energy or other resources (Bakker and Demeroti, 2013). The purpose of the present research was to determine the relationship between job satisfaction and organizational commitment and also to find out any significant variation in job satisfaction and organizational commitment in employees of Islamic and Conventional banks at Hyderabad. Islamic and Conventional bank employees were selected for comparison as there is a basic difference in the working philosophy of the two types of banks i.e., Conventional banking is interest-based while Islamic banking is not.

\subsection{Job Satisfaction}

Several models or theories have been put forward about job satisfaction. According to Hoppock (1935), job satisfaction is actually a combination of internal and external situations that make an employee feel satisfied with his /her job. According to this definition job satisfaction is actually a reflection of both internal and outside forces, especially psychological factors involves how a person feels at the workplace or it is the outcome of numerous attitudes held by an employee. The attitudes most often associated with job satisfaction includes wages, work condition, social relationship on the job, spare time, rapid settlement of compliments, and fair treatment by employer and supervisor.

Job satisfaction as defined by Vroom (1964) is an emotional connection of a person with the workplace. A vastly quoted definition for job satisfaction given by Spector (1997) focuses on overall feelings an employee had about his job and its various aspects. These feelings express the level to which that employee becomes satisfied from the job.

According to Aziri (2011), job satisfaction represents a feeling that is the outcome of the view that a job accomplishes the basic needs of life. By this definition job, satisfaction refers to the feeling of perception that a job fulfills the physical and emotional needs of an employee.

Robbins and Judge (2013) described job satisfaction as positive or negative feelings regarding a job. A highly satisfied individual will have good feelings while an unsatisfied employee will have bad feelings about his/her job.

\subsection{Dimensions of job satisfaction}

\subsubsection{Meaningfulness of the job}

According to Landy (1980), an attractive job which leads to job satisfaction. Luthans (1998) observed that employees become satisfied with their job which is motivating and challenging and provide a position to them. According to Eby \& Freeman (1999), task diversity may aid job satisfaction. Similarly, according to Ting (1997), an employee who possesses a diversity of skills to apply in his job is more satisfied. 
Kousar Khand et al Job Satisfaction and Organizational Commitment in Banking Sector: A Comparative Study of

\subsubsection{Reward system}

According to Olajide (2000), employees realize promotion as the vital accomplishment in their job and when they get it they feel satisfied. Gupta (2004) inspected that more pay and enhanced opportunities lead to higher job satisfaction.

\subsubsection{Job itself}

One of the most essential influences on an employee's job satisfaction depends upon the employee's experience about the job assigned to him by the organization (Sharma and Bhaskar 1991). In a study carried out by Khaleque and Choudhary (1984) on Indian managers, the authors observed that the nature of work and job safety were the most essential factors in determining job satisfaction amongst the top and bottom managers respectively.

\subsubsection{Supervision}

Workers are more probably to become satisfied with their jobs when they receive collaboration from supervisors to complete the assigned tasks (Ting 1997; Cramer 1993; Billingsley \& Cross 1992). These researchers noted that the dissatisfaction of employees from supervisors also leads to a decrease in job satisfaction. Staudt (1997), in his study on community staff also noted that those employees who were satisfied with their supervisors generally showed satisfaction in their jobs. Chieffo (1991) observed a high level of job satisfaction in those employees who were involved by the supervisors in decision makings related to their jobs.

\subsubsection{Coworkers}

Mowday \& Sutton (1993) found that job satisfaction was more in employee's who had opportunities for communications with others on the job. Wharton \& Baron (1991) revealed that an enhanced connection between the employees at work improves the level of job satisfaction. These social relations within the workplace encompass an important component in which employees feel value and recognition (Staudt 1997).

\subsection{Organizational commitment}

Organizational commitment has three main components (Porter et al. 1974), which are:

1. Strong trust in and recognition of the organization's goals,

2. A motivation to positively act for the benefit of the organization,

3. An explicit want to continue the organizational association.

Organizational commitment generates belief between employees, managers, owners of units, and other linked parties in an organization. As per Mowday and Porter (Employee-Organization Linkages, 1982) commitment refers to the following three characteristics:

1. Ambition to 'stay' a part of the organization.

2. Trust in \&reacceptance of values \& goals of the organization.

3. Enthusiasm to utilize major endeavors for the benefit of the organization. 
Kousar Khand et al Job Satisfaction and Organizational Commitment in Banking Sector: A Comparative Study of Conventional and Islamic Banksy

\subsubsection{Types of organizational commitment}

Organizational commitment includes affective, continuance, and normative commitments (Meyer \& Allen 1997; Dunham et al 1994).

\subsubsection{Affective commitment}

Affective commitment according to Allen and Meyer (1990) is the emotional connection of an employee with its organization.

\subsubsection{Continuance commitment}

Continuance commitment according to Becker (1960) is the level to which an employee is committed to continuing with the organization because of giving up benefits related to investments in the organization.

\subsubsection{Normative commitment}

Normative commitment according to Meyer (1993) is the degree to which an employee is grateful to continue with the organization.

\section{Literature Review}

Nartey (2018) investigated the dynamism of the relationship between organizational support, teachers' job satisfaction, and commitment in colleges of education in Ghana. Data were collected from 59 teachers of education colleges through interviews and used a qualitative approach to analyze the data. The outcome of the study reveals that the teachers were less committed to the institution owing to a poor working environment.

Carvalho et al (2018) explored the relationship between four types of organizational culture (clan, hierarchy, adhocracy, and market) with both three dimensions of organizational commitment (affective, normative and instrumental) and job satisfaction dimensions (relationship, reward and nature of work) in banking sector of Brazil. Data was collected from bank clerks of 26 Brazilian states and Federal district through questionnaire and was analysed by using exploratory factor analysis (EFA) followed by multiple regression in order to confirm the association between different variables. The results revealed significant association of Clan Hierarchy Cultures with other variables of the study.

Shrivastava (2018) in India examined the effectiveness of performance management system and its relationship with employee job satisfaction and organizational commitment. Primary data was collected from employees of banks HDFC, ICICI, AXIX through questionnaire and secondary data through website, books. Results of the study show that there is significant association between performance management system and job satisfaction and reasonable commitment between employee job satisfaction and organizational commitment. The author concluded that effective performance management system is important to develop loyalty and keep employee satisfied.

Najeeb et al (2018) inspected the impact of knowledge management practices and organizational commitment on employee job satisfaction in banking sector of Pakistan. Primary data was gathered through both face to face and online web- based questionnaires. Results of the study suggest that there is significant correlation between 
Kousar Khand et al Job Satisfaction and Organizational Commitment in Banking Sector: A Comparative Study of

organization commitment and knowledge management practices especially intraorganizational knowledge sharing, knowledge application and knowledge creation, with high level of employee job satisfaction. The authors advice bank managers to adopt knowledge management practices and organizational commitment activities in their organizations in order to improve performance of worker and their well-being at work.

Yosef (2017) investigated the direct and indirect association between job satisfaction, organizational commitment and attitudes towards organizational change and its dimensions. For this purpose, author collected data through questionnaires from 352 employees of local government departments of the Emirate of RAK, UAE. The results demonstrate that employees were highly satisfied with supervisors and co-workers, moderately satisfied with working condition and job security and least satisfied with pay and promotion.

Musringudin et al (2017) in Jakarta conducted research study on principles of public high school to measure the effect degree of organizational justice, job satisfaction and organizational commitment on organizational citizenship behaviour. Data were collected through questionnaires from 90 principles selected by random sampling technique and path analysis was used to calculate the data. Result of the study shows positive effect of organizational justice, job satisfaction, and organizational commitment on organizational citizenship behaviour of the principles.

Budihardio (2017) examined the relationship between job satisfaction and affective commitment; between affective commitment and cooperate performance and between organizational learning climate and cooperative performance. Data collected from 27 senior managers through questionnaires were statistically analysed. Results suggest significant positive association between job satisfaction and affective commitment and between both affective commitment and organizational learning with corporate performance. Affective commitment seems to play a major role in achieving high corporate performance.

Freund (2015) in his study examined the association of affective and continuance organizational commitments, career commitments, and job involvement with job satisfaction at 3 intervals. Data were collected from 122 employees working at an Israeli nonprofit organization. The results showed that time elapsed between the measurements of multiple commitments and job satisfaction was a major factor affecting the worth of multiple commitments as predictor of job satisfaction.

Gupta (2015) in his study carried out in Kolkata and its adjoining areas examined job satisfaction and organizational commitment present in both part time and guest lecturers of government funded colleges. The findings of the study showed significant difference in job satisfaction and organizational commitment present in part time and guest lectures. Job satisfaction was found to be higher in guest lecturers, whereas organizational commitment in part time teachers.

Dooty, Fahim \& Sultana (2015) in a comparative study evaluated employee's satisfaction in Islamic and Conventional banks in Bangladesh. Fifty samples were collected from each type of banks through self-structured questionnaire. Statistical 
Kousar Khand et al Job Satisfaction and Organizational Commitment in Banking Sector: A Comparative Study of

analyses of the data showed that satisfaction level of employee was same for both types of banks. However, employee's satisfaction was higher in Conventional banks as compared to Islamic in terms of communication indicators.

Iden (2014) investigated the classical determinates of job satisfaction and organizational commitment valid for the Norwegian context with emphasis on multicultural work environments and also inspected whether employees with different cultural backgrounds in Norwegian based companies have a different level of job satisfaction and organizational commitment or not. The general analysis was used to confirm the presence of cultural differences based on power distance in a Norwegian context. Results indicated that some of the classical determinants extracted from theory had a positive effect on job satisfaction and organizational commitment, while, no difference in job satisfaction and organizational commitment was seen in workers from various backgrounds in the multicultural work environment in Norway except that the supervisors were perceived differently by foreigners and Norwegians.

Kristatnto (2014) in Jakarta examined the difference in organizational commitment between employees of Conventional and sharia-based banks. The study involved 342 employees and the obtained data was statistically analyzed. The results of the study disclosed that affective commitment for both banks was identical. Furthermore, continuance commitment and normative commitment were high in Conventional bank employees as against the sharia banks.

Suma \& Lesha (2013) in their study in Shkoder, Albania investigated the levels of employee job satisfaction with job dimensions and studied organizational commitment in government administration. Descriptive and inferential statistical techniques were employed to analyze the data. The findings of the study showed that job dimensions such as salary, opportunities for promotion, supervision, coworkers, and work-itself were significantly positively correlated with organizational commitment and job satisfaction.

Imam et al., (2013) investigated the effect of job satisfaction on affective, continuance, and normative commitments. Data was collected in Punjab through convenience sampling. The data were analyzed using correlation and regression. The findings revealed a positive effect of job satisfaction on all three facets of organizational commitment. Job satisfaction was noticed to have greater predictability for affective commitment than the other facets of organizational commitment.

Naqvi (2012) in his study on banks inspected the impact of intrinsic and extrinsic mechanisms of job satisfaction on organizational commitment. For this purpose, he collected data from 310 employees belonging to Lahore, Sargodha, Karachi, and Islamabad banks. Regression was used to analyze the data. Results showed that both components of job satisfaction were positively related to organizational commitment.

Adekola (2012) carried out research to see organizational commitment present in 150 different category employees of government and private sector universities in Nigeria. Z-test and regression were used for data analysis. It was found that employees in public 
Kousar Khand et al Job Satisfaction and Organizational Commitment in Banking Sector: A Comparative Study of

sector universities had more organizational commitment than that of private universities.

Ismail (2012) in a study carried out in Kelantan investigated the connection between organizational commitment and job satisfaction in the staff of universities and affiliated colleges. Primary and secondary data were statistically analyzed. The findings of the study revealed no significant association between organizational commitment and job satisfaction.

Malik et al., (2010) studied the connection of teacher's job satisfaction with job dimensions based on perceived organizational commitment. They also investigated the extent to which the faculty of two government sector universities were loyal and satisfied with different job dimensions. Data was collected from 331 survey questionnaires filled out from teaching faculty and analyzed by one-sample t-test and stepwise regression. It was seen that pay satisfaction, quality of supervision, and workitself had a significant direct impact on the organizational commitment of the employees.

Sonia (2010) studied organizational commitment and job satisfaction in 300 software industry employees in Bangalore, India., Karl Pearson's correlation coefficient, ANOVA, and Friedman test were applied to analyze the data.it was observed that overall organizational commitment was satisfactory in employees. However, higher inconsistency was noted with affective commitment. Job satisfaction was noted to be highest for continuance commitment representing that employees remain in an organization because they feel the cost of leaving the organization or trouble associated to go somewhere else. Employees in IT showed only a reasonable level of job satisfaction as they were less satisfied with the salary, supervision, working hours, and appreciation from management.

In the present study, we have simultaneously examined both organizational commitment and the level of job satisfaction in employees of Islamic and Conventional banks at Hyderabad. The main purpose of this research was to see any major difference in the level of job satisfaction and organizational commitment present in employees of Islamic and Conventional banks by measuring a few new variables like meaningfulness of job, reward system, job itself, supervision, and co-workers. From the findings of this research, it is hoped that The Human Resource Management department of both types of banks will become benefited as they will come to know how much job satisfaction and organizational commitment occurs in their employees. In this way, they can plan strategies to improve their level of job satisfaction and organizational commitment and hence enhance their productivity performance and reduce dissatisfaction.

\section{Problem Statement}

As there is a basic difference in the working philosophy of Islamic and Conventional banks (Conventional banking is interest-based while Islamic banking is not), so the level of job satisfaction and organizational commitment in employees of both types of banks can be different. 
Kousar Khand et al Job Satisfaction and Organizational Commitment in Banking Sector: A Comparative Study of

\subsection{Research Objectives}

The research objectives of the present study were:

1. To find out the extent of job satisfaction in employees of Islamic and Conventional Banks.

2. To investigate the extent of organizational commitment present in employees of Islamic and Conventional Banks.

3. To establish the facets that contribute to job satisfaction in banking sector employees.

4. To observe any association between job satisfaction and organizational commitment.

5. To determine any significant difference between employees of Islamic and Conventional banks with respect to extent of job satisfaction and organizational commitment.

\subsection{Research Hypotheses}

H1: Job satisfaction has a significant influence on affective, continuance, and normative commitments.

H2: Employees in the banking sector have a correlation with various job facets/dimensions such as meaningfulness of the job, reward system, job-itself, supervision, and coworkers.

H3: Job satisfaction has a significant association with organizational commitment in employees serving in banks.

H4: Job satisfaction and organizational commitment are different in employees serving in Islamic and Conventional Banks.

\section{Research Methods}

\subsection{Data collection method}

Primary data was gathered from employees of 10 banks (5 Islamic and 5 Conventional) by using a structured questionnaire.

\subsection{Research population}

The research population included the employees and managers in major Islamic and Conventional banks of Hyderabad city. The banks selected for the present study from among the Islamic banks were Meezan Bank, Al Barka Bank, Bank Islami, Dubai Islamic Bank, and Burj Bank; and from Conventional banks were Allied Bank Ltd., United Bank Ltd., Soneri Bank, MCB and Habib Bank Ltd.

\subsection{Sample size}

The total no of staff serving in major Islamic and Conventional banks at Hyderabad was 1022 and 30\%of that i.e., 300 were randomly selected for the present study.

\subsection{Sampling technique}

Simple random sampling technique was used to select 150 employees each from Islamic and Conventional Banks. 
Kousar Khand et al Job Satisfaction and Organizational Commitment in Banking Sector: A Comparative Study of

\subsection{Instrument design}

The questionnaire designed had three sections of which section A dealt with demographical information of the responding bankers. It included questions to get information about age, gender, marital status, education level, and job group along with job experience. In section B items of job satisfaction such as the meaningfulness of the job, reward system, the job itself, supervision, and coworkers were included whereas, in section C affective, continuance, and normative organizational commitments present in Islamic and Conventional banks employees at Hyderabad city was determined.

\subsection{An instrument of Job Satisfaction}

The job description index (JDI) proposed by Smith (1969) was used to measure job satisfaction. A 19-item questionnaire, as used by Wavinya (2013), was administered to respondents who were provided the level of agreement and disagreement with each statement at a Likert scale (1; strongly disagree, 5 ; strongly agree).

\subsection{The instrument of Organizational Commitment}

Affective, continuance and normative organizational commitments of the respondents were measured by using the 24-item scale (Allen \& Meyer, 1990). This scale was also adopted by Najafi et al., (2011). Responding bankers had to tick their level of agreement and disagreement with each statement at a Likert scale (1; strongly disagree, 5; strongly agree).

\section{Data analysis}

A normality test was used to know whether the sample drawn was from a normally distributed population or not. Linear Regression was employed to examine the impact of job satisfaction on normative, continuance, and affective commitments, while Spearman Correlation test was applied to see any correlation between the variables involved in hypothesis $2 \& 3$. The Mann-Whitney test was used to compare the means of job satisfaction and organizational commitment in employees serving at Islamic and Conventional banks in order to prove or reject hypothesis 4 .

\subsection{Results}

\subsubsection{Response Rate}

Three hundred questionnaires were distributed to employees of 10 banks, of which 220 were returned back duly filled in by the respondents. The filled in questionnaires constituted 73.33\% response rate. According to Mugenda and Mugenda (1999), 70\% and above response rate is admirable and sufficient for analysis and reporting.

\subsubsection{Reliability Analysis}

Reliability analysis was performed by using SPSS version 22. Cronbach's Alpha of the variables for job satisfaction and organizational commitment (Table 1) indicates that every variable used in the present study has satisfactory reliability statistics. 
Kousar Khand et al Job Satisfaction and Organizational Commitment in Banking Sector: A Comparative Study of

Table 1 Result of Reliability Test

\begin{tabular}{|l|l|l|l|}
\hline Instruments & No of Items & $\begin{array}{l}\text { Cronbach's } \\
\text { Alpha }\end{array}$ & Result* \\
\hline Job Satisfaction & 19 & 0.847 & Reliable \\
\hline Organizational Commitment & 18 & 0.852 & Reliable \\
\hline
\end{tabular}

*Reliable if Cronbach's alpha >0.7 according to Murphy and Balzer (1989).

\subsubsection{Demographic Characteristics of the Respondents}

The demographic characteristics of the respondents calculated in percentages are presented in table 2 . The data shows that the majority of the respondents $(61 \%)$ belonged to age group 26-35 years; were males (63\%); were unmarried (57\%); and postgraduates $(71 \%)$.

Table 2 Demographic characteristics of the Participants

\begin{tabular}{|l|l|l|}
\hline Participants & Frequency & Percentage \\
\hline $\begin{array}{l}\text { Age group } \\
\text { (in years) }\end{array}$ & 48 & \\
\hline $19-25$ & 133 & 22 \\
\hline $26-35$ & 39 & 61 \\
\hline $36-45$ & 139 & 18 \\
\hline Gender & 81 & \\
\hline Male & & 63 \\
\hline Female & 125 & 37 \\
\hline Marital Status & 89 & 57 \\
\hline Single & 06 & 41 \\
\hline Married & 157 & 03 \\
\hline Divorce & 18 & 21 \\
\hline Educational Level & 45 & 08 \\
\hline Intermediary & & \\
\hline Undergraduate & & \\
\hline Postgraduate & & \\
\hline
\end{tabular}

Sukkur IBA Journal of Management and Business - SIJMB | Vol 7 No. 1 January - June 2020 @ Sukkur IBA University 
Kousar Khand et al Job Satisfaction and Organizational Commitment in Banking Sector: A Comparative Study of Conventional and Islamic Banksy

\subsubsection{Analysis for Linear Regression}

Table 3 shows the values of R2 which indicates that about $38 \%, 7 \%$, and $40 \%$ of the variations in affective, continuance, and normative commitments respectively has been explained by the job satisfaction (independent variable).

Beta Coefficient of the job satisfaction presented in table 4 indicates that the single unit change in job satisfaction has brought about $81.1 \%, 52 \%$, and $90 \%$ changes in affective, continuance, and normative commitments respectively. As the p-value of the beta was highly significant $(\mathrm{p}<0.05)$, hypothesis 1 of the present study that Job satisfaction has a significant influence on affective, continuance, and normative commitments are accepted.

Table 3 Model summary of the relationship between facets of organizational commitment with job satisfaction

\begin{tabular}{|l|l|}
\hline Organizational commitment facets & R2 \\
\hline Affective Commitment & 0.378 \\
\hline Continues Commitment & 0.066 \\
\hline Normative Commitment & 0.395 \\
\hline
\end{tabular}

Table 4 Beta coefficients

\begin{tabular}{|l|l|l|}
\hline \multicolumn{1}{|c|}{ Model } & $\beta$ & Significant \\
\hline Affective commitment & & \\
Job satisfaction & 0.478 & .001 \\
\hline Continuance commitment & 0.811 & .001 \\
Job satisfaction & 1.421 & .001 \\
\hline Normative commitment & 0.519 & .001 \\
Job satisfaction & 0.649 & .001 \\
\hline
\end{tabular}

Table 5 Correlation between different job facets

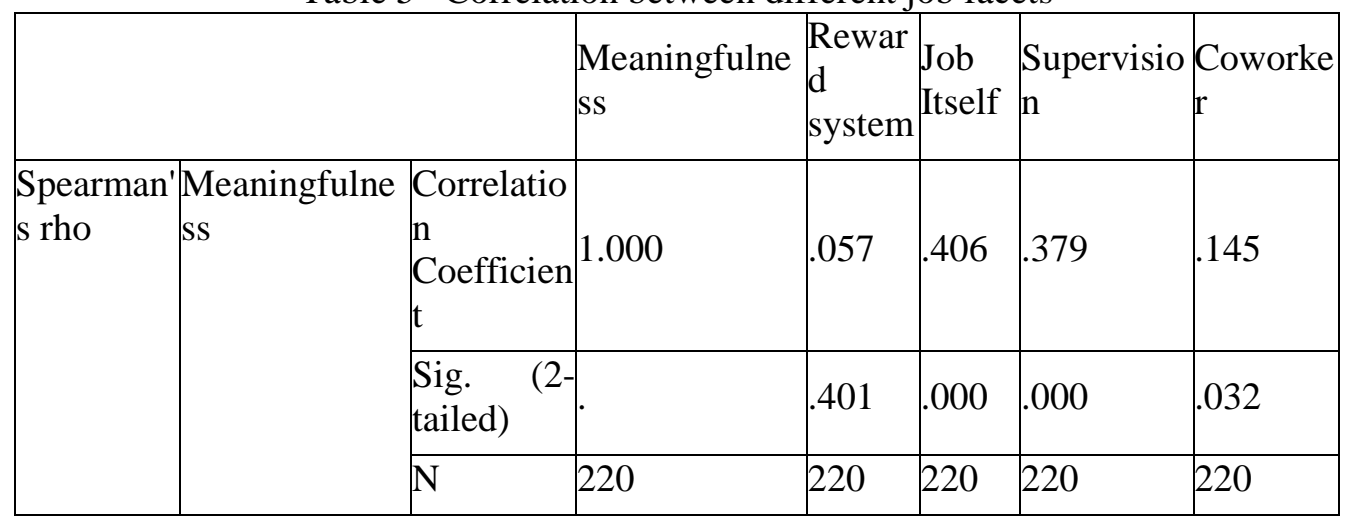


Kousar Khand et al Job Satisfaction and Organizational Commitment in Banking Sector: A Comparative Study of Conventional and Islamic Banksy

\begin{tabular}{|c|c|c|c|c|c|c|}
\hline \multirow[t]{3}{*}{$\begin{array}{l}\text { Reward } \\
\text { system }\end{array}$} & \begin{tabular}{|l} 
Correlatio \\
$n$ \\
Coefficien \\
$t$
\end{tabular} & .057 & 1.000 & $280^{*}$ & .278 & .254 \\
\hline & $\begin{array}{l}\text { Sig. } \\
\text { tailed })\end{array}$ & 401 & & .000 & .000 & .000 \\
\hline & $\mathrm{N}$ & 220 & 220 & 220 & 220 & 220 \\
\hline \multirow[t]{3}{*}{ Job Itself } & $\begin{array}{l}\text { Correlatio } \\
n \\
\text { Coefficien } \\
\text { t }\end{array}$ & .406 & 280 & 1.000 & .630 & .540 \\
\hline & $\begin{array}{l}\text { Sig. } \\
\text { tailed) }\end{array}$ & .000 & .000 & & .000 & .000 \\
\hline & $\mathrm{N}$ & 220 & 220 & 220 & 220 & 220 \\
\hline \multirow[t]{3}{*}{ Supervision } & $\begin{array}{l}\text { Correlatio } \\
\text { n } \\
\text { Coefficien } \\
\text { t }\end{array}$ & .379 & .278 & .630 & 1.000 & .279 \\
\hline & $\begin{array}{l}\text { Sig. } \\
\text { tailed) }\end{array}$ & .000 & .000 & .000 & & .000 \\
\hline & $\mathrm{N}$ & 220 & 220 & 220 & 220 & 220 \\
\hline \multirow[t]{3}{*}{ Coworker } & $\begin{array}{l}\text { Correlatio } \\
n \\
\text { Coefficien } \\
t\end{array}$ & .145 & .254 & .540 & .279 & 1.000 \\
\hline & $\begin{array}{l}\text { Sig. } \\
\text { tailed) }\end{array}$ & .032 & .000 & .000 & .000 & \\
\hline & $\bar{N}$ & 220 & 220 & 220 & 220 & 220 \\
\hline
\end{tabular}

\subsubsection{Analysis for Correlation:}

Table 5 shows the correlation between different job facets such as the meaningfulness of the job, reward system, job-itself, supervision, and coworkers. The data indicate that both job itself and supervisors had a very strong $(\mathrm{P}<0.001)$ correlation with other job facets. The Reward system was seen to have a highly significant $(\mathrm{P}<0.001)$ correlation with job-itself, supervision, and coworkers, whereas coworkers with the job itself, reward system, and supervision. Meaningfulness of the job is also highly significantly correlated with the job itself, coworkers, and supervision. However, no significant $(\mathrm{P}>0.05)$ correlation was found between the meaningfulness of the job and the reward system. 
Kousar Khand et al Job Satisfaction and Organizational Commitment in Banking Sector: A Comparative Study of Conventional and Islamic Banksy

In table 6 relationships between job satisfaction and organizational commitment are depicted. The table discloses that they are significantly correlated $(\mathrm{P}<0.001)$ with each other, thus hypothesis 3 is accepted.

Table 6 Correlation between job satisfaction and organizational commitment

\begin{tabular}{|l|l|l|l|}
\hline Correlations & \multicolumn{2}{l|}{ Job satisfaction } & $\begin{array}{l}\text { Organizational } \\
\text { commitment }\end{array}$ \\
\hline \multicolumn{1}{|l|}{} \\
\hline
\end{tabular}

\subsubsection{Analysis of Mann-Whitney Test}

As the significance level obtained for job satisfaction $(\mathrm{p}=0.514)$ and organizational commitment $(\mathrm{p}=0.098)$ by the Mann-Whitney test (Table 7) was not statically significant $(\mathrm{P}>0.05)$, it indicates that both job satisfaction and organizational commitment was same in employees serving at Islamic and Conventional Banks. Thus, hypothesis 4 of the present study that Job satisfaction and organizational commitment are different in employees serving in Islamic and Conventional banks is rejected.

With respect to job satisfaction, our findings are in full agreement with Dooty, Fahim $\&$ Sultana (2015), while for the organizational commitment our findings are in line with Kristatnto (2014).

Table 7: Result of Mann-Whitney Test

\begin{tabular}{|l|l|l|}
\hline & Job satisfaction & $\begin{array}{l}\text { Organizational } \\
\text { commitment }\end{array}$ \\
\hline Asymp Sig. (2-tailed) & .514 & .098 \\
\hline
\end{tabular}


Kousar Khand et al Job Satisfaction and Organizational Commitment in Banking Sector: A Comparative Study of

\section{Conclusions}

From the results of this study, it may be concluded that Job satisfaction has a significant influence on affective, continuance, and normative commitments. The job itself and supervisors are highly significantly correlated with other job facets. A Reward system is seen to be significantly correlated with job-itself, supervision, and coworkers, whereas coworkers with the job itself, reward system, and supervision. Meaningfulness of the job is also highly significantly correlated with the job itself, coworkers, and supervision. However, no significant connection was found between the meaningfulness of the job and the reward system. A highly significant positive correlation was found between job satisfaction and organizational commitment in bank employees at Hyderabad city. The level of job satisfaction was the same in employees of Islamic and Conventional Banks.

The same types of studies are recommended to be carried out in those countries where both Islamic and Conventional banking systems are operating simultaneously. In the light of findings of the present study, it is strongly recommended that every year HRM department of both types of banks should carry out this type of confidential structured survey to measure the level of job satisfaction and organizational commitment present in their employees. In this way, both types of banks can plan strategies to improve the level of job satisfaction and organizational commitment in their employees and hence enhance their productivity performance to achieve the targets set for the next year

The limitation of the present study includes a small sample size of both conventional and Islamic banks located in Hyderabad city only.

\section{References}

ADEKOLA, B. (2012) The impact of organizational commitment on job satisfaction: A study of employees at nigerian universities, International Journal of Human Resource Studies, Vol. 2, No. 2, pp. 1-17

ALLEN, N.J \& MEYER, J.P. (1990) The measurement and antecedents of affective, continuance and normative commitment to the organization, Journal of occupational psychology, Vol. 63 No.1 pp. 1-18

AZIRI, B. (2011), Job Satisfaction: A Literature Review, Management Research and Practice, Vol.3 No.4, pp. 77-86.

BAKKER, A. B., \& DEMEROUTI, E. (2013) the spillover-crossover model. New Frontiers in Work and Family Research. Hove: Psychology Press.

BECKER, H.S. (1960) Notes on the Concept of Commitment. American Journal of Sociology, Vol. 66 No.1 pp. 32-42

BUDIHARDJO, A. (2017). The relationship between job satisfaction, affective commitment, organizational learning climate and corporate performance. GSTF Journal on Business Review (GBR), 2(4).

CARVALHO, C. R. S. P., CASTRO, M. A. R., SILVA, L. P., \& CARVALHO, L. O. P. (2018). The Relationship Between Organizational Culture, Organizational Commitment and Job Satisfaction. REBRAE, 11(2), 201-215.

CHIEFFO, A.M. (1991) Factors contributing to job satisfaction and organisational commitment of community college leadership teams. Community College Review, Vol. 19 No.2, pp.15-25.

Sukkur IBA Journal of Management and Business - SIJMB | Vol 7 No. 1 January - June 2020 @) Sukkur IBA University 
Kousar Khand et al Job Satisfaction and Organizational Commitment in Banking Sector: A Comparative Study of

CRAMER, D. (1993) Tenure, commitment, and satisfaction of college graduates in an engineering firm. Journal of Social Psychology, Vol. 133 No.6, pp.791-797

DOOTY EN, FAHIM ST \& SULTANA. (2015) a comparative analysis on employee satisfaction a study on Conventionaland Islamic banks of Bangladesh Romanian Economic Business Review, Vol. 10 No. 1 pp. 99-105.

DUNHAM, R.B., GRUBE, J.A., \& CASTENADA, M.B. (1994) Organizational commitment: The utility of an integrativedefinition. Journal of Applied Psychology, Vol. 79 No.3, pp. 370380.

EBY, L.T., FREEMAN, D.M., RUSH, M.C., \& LANCE, C.E. (1999) Motivational bases of affective organisational commitment: A partial test of an integrative theoretical model. Journal of Occupational \& Organisational Psychology, Vol 72 No. 4 pp.463-484.

FREUND A (2015) Do Multiple Commitments predict Job Satisfaction in Third sector organization?A longitudinal Analysis, Humanistic Management Research Paper No. 26/15, 1-29.

GUPTA, C. (2004) Human Resource Management (6th Edition). New Delhi: SultanChand.

GUPTA, D. (2015). A comparative study of job satisfaction and organizational commitment as work place values among part-time lecturers and guest lecturers of government aided colleges in West Bengal. International Journal of Education and Management Studies, 4(4)

HASHMI, M. M., \& NAQV, D. I. (2012) Investigating Organizational Commitment as the Outcome of Job Satisfaction: A Study of Banking Sector of Pakistan. International Journal of Learning \& Developmen Vol. 2, No. 4, pp. 150-158.

HOPPOCK, R. (1935) Job Satisfaction. New York: Harper Brothers.

IDEN, L. M. (2014). Job satisfaction and organizational commitment in multicultural work environments in Norway, Master thesis in international business, norwegian school of economics

IMAM, A., RAZA, A., SHAH, F.T., \& RAZA, H. (2013). Impact of job satisfaction on facet of organizational commitment (affective, continuance and normative commitment): A study of banking sector employees of Pakistan. World Applied Sciences Journal Vol. 28 No.2, pp. 271-277.

ISMAIL, N. (2012). Organizational commitment and job satisfaction among staff of higher learning education institutions in kelantan, Doctoral dissertation,universiti utara malaysia.

KHALEQUE, A. AND CHOUDHARY, N. (1984) Job Facets and overall job satisfaction of Indutrial Managers, Indian Journal of Industrial Relations, Vol.20 No. 1 1984,pp. 55-64.

KRISTANTO S.B (2014) Organizational commitment differences Islamic vs. Conventional banks, Social science research network. 1-12

LANDY, F. J. , \& TRUMBO, D.A. (1980). Psychology of Work Behavior. Pacific Grove, CA: Brooks/Cole.

LUTHANS, F. (1998). Organisational Behaviour. (8th ed). Boston: Irwin McGraw-Hill.

LUTHANS, FRED. (1998). Organizational Behavior. Singapore: McGraw-Hill. Panggabean, Mutiara S. 2001. Perbedaan Komitmen Organisasional Berdasarkan Karakteristik Individu. Media Riset Bisnis dan Manajemen, Vol 1, No. 2, pg: 89 - 124.

MALIK, M. E., NAWAB, S., NAEEM, B., \& DANISH, R. Q. (2010). Job satisfaction and organizational commitment of university teachers in public sector of Pakistan. International Journal of Business and Management, Vol.5 No.6, p17.

MEYER, J.P., ALLEN, N.J. \& SMITH, C.A. (1993) Commitment to Organizations and Occupations: Extension and Test of a Three-Component Conceptualization”. Journal of Applied Psychology, Vol. 78 No.4, pp.538-551

Sukkur IBA Journal of Management and Business - SIJMB | Vol 7 No. 1 January - June 2020 @) Sukkur IBA University 
Kousar Khand et al Job Satisfaction and Organizational Commitment in Banking Sector: A Comparative Study of Conventional and Islamic Banksy (pp. 107-123)

MEYER, J.P. AND N.J. ALLEN. (1997) Commitment in the Workplace: Theory, Research and Application. Thousand Oaks, CA: Sage.

MOWDAY, R., \& SUTTON, R. (1993) Organisational behaviour: Linking individuals and groups to organisational context. Annual Review of Psychology Vol.44 No. 1 pp.195229.

MOWDAY, R.T., PORTER, L.W. \& STEERS, R. M. (1982). Employee-Organization Linkages: The Psychology of Commitment, Absenteeism and Turnover, New York, Academic Press. In Reichers, A.E. A Revicev and Reconceptualization of Organizational Commitment. Academy of Management Review, Vol.10 No.3, pp.465-4

MOWDAY RT., PORTER LW \&. STEERS RM, (1982) "Employee- Organization Linkages: The Psychology of Commitment, Absenteeism and Turnover," Academic Press, Inc., New York,

MURPHY, K. AND W. BALZER. (1989) Rate Error and Rating Accuracy. Journal of Applied Psychology, 71(4): 619-24.

MUSRINGUDIN, M., AKBAR, M., \& KARNATI, N. (2017). The effect of organizational justice, job satisfaction, and organizational commitment on organizational citizenship behavior (ocb) of the principles. Ijer-indonesian journal of educational review, 4(2), 155165.

NAJAFI, S., NORUZY, A., AZAR, H. K., NAZARI-SHIRKOUHI, S., \& DALVAND, M. R. (2011). Investigating the relationship between organizational justice, psychological empowerment, job satisfaction, organizational commitment and organizational citizenship behavior: An empirical model. African Journal of Business Management, 5(13), 5241.

NAJEEB, M. M., HANIF, M. I., \& HAMID, A. B. A. (2018). The impact of Knowledge Management (KM) and Organizational Commitment (OC) on employee job satisfaction (EJS) in banking sector of Pakistan. International Journal of Management Excellence, 11(1), 1476-1491.

NARTEY, L. T. (2018). Organisational support, Teachers' Job Satisfaction and Commitment in Colleges of Education in Ghana: A Qualitative Study. International Journal of Innovative Research and Development, 7(8).

NAQVI, S. M., ISHTIAQ, M., KANWAL, N., \& ALI, M. (2013). Impact of Job Autonomy on Organizational Commitment and Job Satisfaction: The Moderating Role of Organizational Culture in Fast Food Sector of Pakistan. International Journal of Business and Management; Vol 8 No.17, pp 92-102.

OLAJIDE, A. (2000). Getting The Best Out Of Employees In Developing Economy. APersonnel Psychology Guests Lecturer Series. Department of Guidance andCounselling, University Of Ibadan, Nigeria.Vol.45 No.3 pp. 253-262.

PORTER, L. W., STEERS, R. M., MOWDAY, R. T., \& BOULIAN, P. V. (1974). Organizational commitment, job satisfaction, and turnover among psychiatric technicians. Journal of applied psychology, Vol.59 No.5, pp.603.

ROBBINS, S.P. AND JUDGE, T.A. (2013). Organizational Behaviour. (13th ed.) New Jersey: Prentice-Hall

SAIMIR SUMA, J. L. (2013). Job satisfaction and organizational commitment: the case of shkodra municipality. European Scientific Journal Vol.9 No.17, pp.41-51.

SHARMA, B., \& BHASKAR, S. (1991). Determinants of job satisfaction among engineers in a public sector undertaking. Journal of Management,Vol. 20 No.4 pp. 23-34.

SHRIVASTAVA, P. (2018). Impact of effectiveness of performance management system on employee satisfaction and commitment

Sukkur IBA Journal of Management and Business - SIJMB | Vol 7 No. 1 January - June 2020 @ Sukkur IBA University 
Kousar Khand et al Job Satisfaction and Organizational Commitment in Banking Sector: A Comparative Study of

SMITH PC.,. KENDALLT LM \& HULIN CL. (1969), "The Measurement of Satisfaction in Work and Retirement," Rand Mc Nally, Chicago.

SONIA, J. (2010). organizational commitment and job satisfaction: a study of employees in the information technology industry in Bangalore, India (Doctoral dissertation, Christ University).

SPECTOR, P. (1997). Job Satisfaction: Application, Assessment, Causes and Consequences. California: Sage.

STEWART, G. L. (1996). Reward structure as a moderator of the relationship between extraversion and sales performance. Journal of Applied Psychology, Vol.81 No.6 pp. $619-627$.

STAUDT, M. (1997). Correlates of job satisfaction in school social work. Social Work in Education, Vol.19, No.1, pp.43-52.

TING, Y. (1997). Determinants of job satisfaction of federal government employees,Public Personnel Management, Vol. 26 No.3, pp.313-334.

VROOM, V. H. (1964). Work and motivation. New York: Wiley.

WAVINYA, M. S. (2013). Relationship between job satisfaction and organizational commitment among public secondary school teachers in nairobi county (doctoral dissertation, school of business, university of nairobi).

WHARTON, A. S., \& BARON, J. N. (1991). Satisfaction?: the psychological impact of gender segregation on women at work. The Sociological Quarterly, 32(3), 365-387.

YOUSEF, D. A. (2017). Organizational commitment, job satisfaction and attitudes toward organizational change: A study in the local government. International Journal of Public Administration, 40(1), 77-88. 